\title{
Data report: boron isotope ratios in interstitial waters from Sites $\mathrm{C} 0021$ and $\mathrm{C0022^{1 }}$
}

\author{
Tomohiro Toki, ${ }^{2}$ Kota Higa, ${ }^{2}$ and Ryuichi Shinjo ${ }^{3}$
}

\section{Chapter contents}

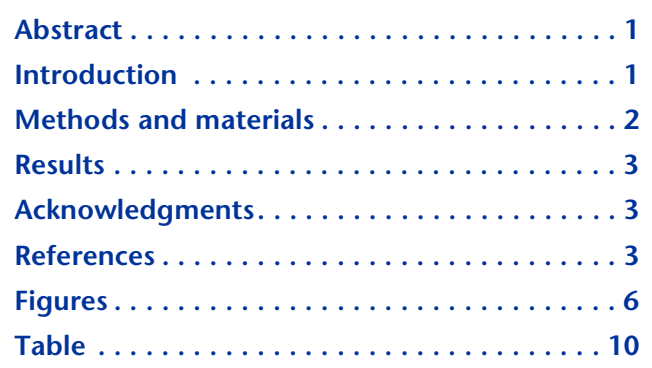

${ }^{1}$ Toki, T., Higa, K., and Shinjo, R., 2015. Data report: boron isotope ratios in interstitial waters from Sites C0021 and C0022. In Strasser, M., Dugan, B., Kanagawa, K., Moore, G.F., Toczko, S., Maeda, L., and the Expedition 338 Scientists, Proceedings of the Integrated Ocean Drilling Program, 338: Yokohama (Integrated Ocean Drilling Program).

doi:10.2204/iodp.proc.338.203.2015

${ }^{2}$ University of the Ryukyus, Department of Chemistry, Biology and Marine Science, Faculty of Science, 1 Senbaru, Nishihara, Okinawa 903-0213, Japan. Correspondence author: toki@sci.u-ryukyu.ac.jp

${ }^{3}$ University of the Ryukyus, Department of Physics and Earth Sciences, Faculty of Science, 1 Senbaru, Nishihara, Okinawa 903-0213, Japan.

\section{Abstract}

Surface sediment was sampled from Sites C0021 and C0022 in the Nankai accretionary prism during Integrated Ocean Drilling Program (IODP) Expedition 338. Interstitial waters were extracted from the sediments, and boron isotope ratios $\left(\delta^{11} \mathrm{~B}\right)$ in the interstitial waters were measured. Just below the seafloor at both sites, boron concentrations were higher than that of seawater, and $\delta^{11} \mathrm{~B}$ values were rich in ${ }^{10} \mathrm{~B}$ relative to seawater. Boron concentrations decreased and $\delta^{11} \mathrm{~B}$ increased with increasing depth at both sites. At Site C0022, these values were almost constant around 100 meters below seafloor, and at the bottom of the hole, boron concentrations were increasing and $\delta^{11} \mathrm{~B}$ values were increasing. We did not find anomalies related to lithologic unconformities such as faults and mass transport deposits. This may indicate that it has been some time since the events forming these unconformities, assuming that anomalies existing just after the events were smoothed by diffusion. Thus, these faults and mass transport deposits might currently be inactive.

\section{Introduction}

Boron (B) has two isotopes, ${ }^{10} \mathrm{~B}$ and ${ }^{11} \mathrm{~B}$, with natural abundances of $19.9 \%$ and $80.1 \%$, respectively (Berglund and Wieser, 2011). The element is a useful geochemical tracer given the large relative difference between its two isotopes, its high mobility, and its wide range of isotope ratios at Earth's surface (Barth, 1993). The distribution of B concentrations and isotope ratios in interstitial waters of accretionary prisms in subduction zones provides important information about fluid migration along permeable sand layers and décollements (Deyhle et al., 2004; Gieskes et al., 1989; Teichert et al., 2005; You et al., 1993, 1996).

$\mathrm{B}$ sources tend to have characteristic isotope ratios. In seawater, $\mathrm{B}(\mathrm{OH})_{4}{ }^{-}$is adsorbed onto the surface of settling particles, and $\mathrm{B}$ exists mainly as $\mathrm{B}(\mathrm{OH})_{3}$. Generally, ${ }^{11} \mathrm{~B}$ preferentially condenses in $\mathrm{B}(\mathrm{OH})_{3}$ and ${ }^{10} \mathrm{~B}$ is incorporated in $\mathrm{B}(\mathrm{OH})_{4}^{-}$, leading to isotopic fractionation (Kakihana et al., 1977; Oi et al., 1991; Palmer et al., $1987)$. The $\mathrm{B}$ isotope ratio $\left(\delta^{11} \mathrm{~B}\right)$ in seawater averages $+39.5 \%$ (Spivack and Edmond, 1987). At shallow depth in marine sediments, exchangeable B is desorbed from the surface of sediments, increasing $\mathrm{B}$ concentrations and decreasing $\delta^{11} \mathrm{~B}$ in interstitial wa- 
ters (You et al., 1996). This desorption is related to the decomposition of organic matter during early diagenesis (Brumsack et al., 1992; You et al., 1993). Additionally, B concentrations and $\delta^{11} \mathrm{~B}$ in interstitial waters may be slightly altered by sampling artifacts because of temperature and pressure changes, and several studies corrected observed values (You et al., 1996; Kopf et al., 2000; Deyhle and Kopf, 2002). At greater depths in the sediment, adsorbed B from sediment particles is incorporated into an interlayer of a clay mineral during late diagenesis, and $\mathrm{Si}-\mathrm{O}$ bonds are broken and B substitutes for $\mathrm{Si}$ in the tetrahedral structure during smectite-illite conversion, which generally occurs between $60^{\circ}$ and $160^{\circ} \mathrm{C}$ (Williams et al., 2001). During this process, ${ }^{10} \mathrm{~B}$ is preferentially incorporated into the clay mineral structure, and the residual fluids in interstitial waters from the Cascadia margin have been observed to be ${ }^{11} \mathrm{~B}$-enriched (Teichert et al., 2005). At still greater depths in marine sediments, the temperature increases, porosity decreases, and B in the clay-mineral crystal lattice is released (You and Gieskes, 2001). In subduction zones, such as the Nankai Trough, the Barbados Ridge complex, and the Costa Rica fore arc, increased B concentrations with low isotope ratios have been observed along décollements and fracture zones (Kopf et al., 2000; You et al., 1993, 1995). These features reflect the upward migration of deep-sourced fluids along décollements and fracture zones (Deyhle and Kopf, 2002). Thus, a systematics of B concentrations and isotopic ratios has been used for studies about B sources in interstitial waters and migration processes of interstitial waters.

In this study of a plumbing system in the Nankai accretionary prism, we measured B concentrations and isotopic compositions in interstitial waters from the surface layer of sediments and clarified the presence of deep-sourced fluids, especially along lithologic boundaries formed by faults and mass transport deposits.

\section{Methods and materials}

The Nankai Trough (Fig. F1) is a sediment-filled trench located south of Japan where the Philippine Sea plate is subducting beneath the Eurasia plate at 4.1-6.5 cm/y (Miyazaki and Heki, 2001; Seno et al., 1993). Sediments in the Shikoku Basin on the Philippine Sea plate are accreted to the Eurasia plate at the deformation front, and the accretionary prism is formed on the Eurasia plate. Around the Nankai Trough, large earthquakes accompanied by tsunamis have occurred repeatedly according to historical records (Ando, 1975; Baba et al., 2006; Hori et al., 2004). In Stages 1 and 2 of the Nankai Trough Seis- mogenic Zone Experiment (NanTroSEIZE) project, eight riserless drilling sites and one riser drilling site were drilled during Integrated Ocean Drilling Program (IODP) Expeditions 314, 315, 316, 319, 322, 332, and 333 (Fig. F1A) (Kinoshita, Tobin, Ashi, Kimura, Lallemant, Screaton, Curewitz, Masago, Moe, and the Expedition 314/315/316 Scientists, 2009; Saffer et al., 2009; Underwood et al., 2010; Expedition 332 Scientists, 2011; Expedition 333 Scientists, 2012). In this study, during NanTroSEIZE Stage 3 , a slope of the accretionary prism was drilled during IODP Expedition 338 at two sites. IODP Site C0021 is located on a mass transport deposit, and IODP Site C0022 is located on the hanging wall of a megasplay fault (Fig. F1B). At Site C0021, drilling was between 80 and 195 meters below seafloor (mbsf), and mass transport deposits were observed at 100-115 and 135-180 mbsf. A thick sand layer was observed at 180-195 mbsf (Moore et al., 2014). Site C0022 was drilled to $440 \mathrm{mbsf}$ and penetrated the megasplay fault at $100 \mathrm{mbsf}$, where sediment in the core was deformed about $15 \mathrm{~m}$ above and below this level (Moore et al., 2014).

Extraction of interstitial waters from sediment followed the procedure described in the "Methods" chapter (Strasser et al., 2014). The protocol adheres fundamentally to routine IODP protocols (Expedition 315 Scientists, 2009; Expedition 319 Scientists, 2010), modified during the Ocean Drilling Program (Gieskes, 1991; Murray et al., 2000). Sediment samples were placed into nitrogen-filled glove bags, and their outer surface was scraped off using cleaned spatulas to avoid contamination by water from the circulating drilling mud. Samples were then squeezed by a Manheim-type titanium squeezer (Manheim, 1966) to a maximum pressure of $30 \mathrm{MPa}$. The extracted interstitial water was filtered with a $0.45 \mu \mathrm{m}$ disposable filter and stored in high-density polyethylene sample bottles that had been previously washed with trace metal grade $12 \mathrm{M} \mathrm{HCl}$ and Milli-Q water. These were then acidified with $6 \mathrm{M}$ $\mathrm{HCl}$ with a ratio of $0.4 \mathrm{vol} \%$.

$B$ concentrations in interstitial waters were measured on board the ship using procedures described in the "Methods" chapter (Strasser et al., 2014). Aliquots of $500 \mu \mathrm{L}$ were measured using an inductively coupled plasma-atomic emission spectrometer (ULTIMA 2; Jobin Yvon Horiba). Samples were diluted by 20 times, and the matrix was matched to that of seawater by artificial seawater for accurate analysis. A yttrium solution was added as an internal standard to correct for instrumental drift. The precision was $\pm 2.5 \%$.

To measure B isotope ratios in interstitial waters, B was isolated based on the procedure of Wang et al. 
(2010) using a sealed upside-down beaker. The method uses a microsublimation technique to desalinate sample water, which is independent of matrix effect (Wang et al., 2010). A $30 \mu \mathrm{L}$ aliquot sample was placed at the center of an upward-facing beaker cap, a conical beaker was placed upside-down on the cap creating a tight seal, and the resulting assemblage was heated at $100^{\circ} \mathrm{C}$ overnight, or about $15-17$ h. $\mathrm{B}$ and moisture condensed within the apical end of the beaker were dissolved in $0.15 \mathrm{M} \mathrm{HNO}_{3}+0.015$ $\mathrm{M}$ HF to yield a solution with a B concentration of 50 parts per billion. This solution was introduced into a multicollector inductively coupled plasmamass spectrometer (Neptune Plus; Thermo Fisher Scientific) to measure $\mathrm{B}$ isotope ratios. The isotope ratio was expressed as $\delta^{11} \mathrm{~B}$, the deviation from the international standard material NBS SRM951. Precision was within $\pm 0.7 \%$. The running error during each sample measurement was listed in Table T1; 0.05$0.07 \%$ o $(2 \sigma)$.

\section{Results}

Analytical results are listed in Table T1, and depth profiles of B concentration sand $\delta^{11} \mathrm{~B}$ for Sites C0021 and C0022 are shown in Figures F2 and F3, respectively.

At Site C0021, only one sample just below the seafloor had a high $\mathrm{B}$ concentration and a low $\delta^{11} \mathrm{~B}$ relative to that of seawater $(420 \mu \mathrm{m} ;+39.5 \%$ ) (Fig. F2). At $80 \mathrm{mbsf}$, where drilling operations at the site restarted, B concentration matched that of seawater and gradually decreased with increasing depth. The $\delta^{11} \mathrm{~B}$ value was lowest just below the seafloor and increased with increasing depth. No anomalous B distribution was found in mass transport deposits.

At Site C0022, likewise, only one sample just below the seafloor had a high $\mathrm{B}$ concentration and a low $\delta^{11} \mathrm{~B}$ relative to seawater (Fig. F3). B concentrations gradually decreased and $\delta^{11} \mathrm{~B}$ values increased with increasing depth. Around the megasplay at $\sim 100$ mbsf, both values showed some scatter, which might be caused by local mechanisms (e.g., a submarine microlandslide) which stirred and mixed the sediments to smooth out any variation. Between 100 and 350 mbsf, both values were almost constant.

The fact that at both sites only one sample just below the seafloor had a higher B concentration and lower $\delta^{11} \mathrm{~B}$ than seawater indicates that ${ }^{10} \mathrm{~B}$ is preferentially distributed in interstitial waters. The decrease in $\mathrm{B}$ concentrations and rise in $\delta^{11} \mathrm{~B}$ values with increasing depth indicate that ${ }^{10} \mathrm{~B}$ is preferentially removed from seawater. Similar trends have been observed in interstitial waters from the Costa
Rica margin (Kopf et al., 2000) and the southern Okinawa Trough (Huang et al., 2005). At Site C0022, drilling penetrated the megasplay, but we did not find any signals of deep-sourced fluids. This result suggests that the megasplay fault may not currently be active.

\section{Acknowledgments}

We thank the captain, crew, technicians, and science party of the D/V Chikyu for their assistance during Integrated Ocean Drilling Program Expedition 338. Samples and data were provided by IODP. Funding was provided by the Japan Agency for Marine-Earth Science and Technology for IODP postexpedition research.

\section{References}

Ando, M., 1975. Source mechanisms and tectonic significance of historical earthquakes along the Nankai Trough, Japan. Tectonophysics, 27(2):119-140. http:// dx.doi.org/10.1016/0040-1951(75)90102-X

Baba, T., Cummins, P.R., Hori, T., and Kaneda, Y., 2006. High precision slip distribution of the 1944 Tonankai earthquake inferred from tsunami waveforms: possible slip on a splay fault. Tectonophysics, 426(1-2):119-134. http://dx.doi.org/10.1016/j.tecto.2006.02.015

Barth, S., 1993. Boron isotope variations in nature: a synthesis. Geologische Rundschau, 82(4):640-651. http:// dx.doi.org/10.1007/BF00191491

Berglund, M., and Wieser, M.E., 2011. Isotopic compositions of the elements 2009 (IUPAC Technical Report). Pure and Applied Chemistry, 83(2):397-410. http:// dx.doi.org/10.1351/PAC-REP-10-06-02

Brumsack, H.-J., Zuleger, E., Gohn, E., and Murray, R.W., 1992. Stable and radiogenic isotopes in pore waters from Leg 127, Japan Sea. In Pisciotto, K.A., Ingle, J.C., Jr., von Breymann, M.T., Barron, J., et al., Proceedings of the Ocean Drilling Program, Scientific Results, 127/128 (Pt. 1): College Station, TX (Ocean Drilling Program), 635650. http://dx.doi.org/10.2973/odp.proc.sr.1271281.165.1992

Deyhle, A., and Kopf, A., 2002. Strong B enrichment and anomalous $\delta^{11} \mathrm{~B}$ in pore fluids from the Japan Trench forearc. Marine Geology, 183(1-4):1-15. http:// dx.doi.org/10.1016/S0025-3227(02)00186-X

Deyhle, A., Kopf, A., Frape, S., and Hesse, R., 2004. Evidence for fluid flow in the Japan Trench forearc using isotope geochemistry $(\mathrm{Cl}, \mathrm{Sr}, \mathrm{B})$ : results from ODP Site 1150. Island Arc, 13(1):258-270. http://dx.doi.org/ 10.1111/j.1440-1738.2003.00424.x

Expedition 315 Scientists, 2009. Expedition 315 methods. In Kinoshita, M., Tobin, H., Ashi, J., Kimura, G., Lallemant, S., Screaton, E.J., Curewitz, D., Masago, H., Moe, K.T., and the Expedition 314/315/316 Scientists, Proceedings of the Integrated Ocean Drilling Program, 314/315/ 316: Washington, DC (Integrated Ocean Drilling Pro- 
gram Management International, Inc.). http:// dx.doi.org/10.2204/iodp.proc.314315316.122.2009

Expedition 319 Scientists, 2010. Methods. In Saffer, D., McNeill, L., Byrne, T., Araki, E., Toczko, S., Eguchi, N., Takahashi, K., and the Expedition 319 Scientists, Proceedings of the Integrated Ocean Drilling Program, 319: Tokyo (Integrated Ocean Drilling Program Management International, Inc.). http://dx.doi.org/10.2204/ iodp.proc.319.102.2010

Expedition 332 Scientists, 2011. Site C0002. In Kopf, A., Araki, E., Toczko, S., and the Expedition 332 Scientists, Proceedings of the Integrated Ocean Drilling Program, 332: Tokyo (Integrated Ocean Drilling Program Management International, Inc.). http://dx.doi.org/10.2204/ iodp.proc.332.104.2011

Expedition 333 Scientists, 2012. Expedition 333 summary. In Henry, P., Kanamatsu, T., Moe, K., and the Expedition 333 Scientists, Proceedings of the Integrated Ocean Drilling Program, 333: Tokyo (Integrated Ocean Drilling Program Management International, Inc.). http://dx.doi.org/ 10.2204/iodp.proc.333.101.2012

Gieskes, J., Blanc, G., Vrolijk, P., Moore, J.C., Mascle, A., Taylor, E., Andrieff, P., Alvarez, F., Barnes, R., Beck, C., Behrmann, J., Brown, K., Clark, M., Dolan, J., Fisher, A., Hounslow, M., McLellan, P., Moran, K., Ogawa, Y., Sakai, T., Schoonmaker, J., Wilkins, R., and Williams, C., 1989. Hydrogeochemistry in the Barbados accretionary complex: Leg 110 ODP. Palaeogeography, Palaeoclimatology, Palaeoecology, 71(1-2):83-96. http://dx.doi.org/ 10.1016/0031-0182(89)90031-X

Gieskes, J.M., Gamo, T., and Brumsack, H., 1991. Chemical methods for interstitial water analysis aboard JOIDES Resolution. Ocean Drilling Program Technical Note, 15. http://dx.doi.org/10.2973/odp.tn.15.1991

Hori, T., Kato, N., Hirahara, K., Baba, T., and Kaneda, Y., 2004. A numerical simulation of earthquake cycles along the Nankai Trough in southwest Japan: lateral variation in frictional property due to the slab geometry controls the nucleation position. Earth and Planetary Science Letters, 228(3-4):215-226. http://dx.doi.org/

10.1016/j.epsl.2004.09.033

Huang, K.-F., You, C.-F., Shen, M.-L., and Lin, H.-L., 2005. Geochemistry of major constituents, boron and boron isotopes in pore waters from ODP Site 1202, Okinawa Trough. Terrestrial, Atmospheric and Oceanic Sciences, 16(1):75-93. http://tao.cgu.org.tw/index.php?id=565

Kakihana, H., Kotaka, M., Satoh, S., Nomura, M., and Okamoto, M., 1977. Fundamental studies on the ionexchange separation of boron isotopes. Bulletin of The Chemical Society of Japan, 50(1):158-163. http:// dx.doi.org/10.1246/bcsj.50.158

Kinoshita, M., Tobin, H., Ashi, J., Kimura, G., Lallemant, S., Screaton, E.J., Curewitz, D., Masago, H., Moe, K.T., and the Expedition 314/315/316 Scientists, 2009. Proceedings of the Integrated Ocean Drilling Program, 314/315/ 316: Washington, DC (Integrated Ocean Drilling Program Management International, Inc.). http:// dx.doi.org/10.2204/iodp.proc.314315316.2009

Kopf, A., Deyhle, A., and Zuleger, E., 2000. Evidence for deep fluid circulation and gas hydrate dissociation using boron and boron isotopes of pore fluids in forearc sediments from Costa Rica (ODP Leg 170). Marine Geology, 167(1-2):1-28. http://dx.doi.org/10.1016/S00253227(00)00026-8

Manheim, F.T., 1966. A hydraulic squeezer for obtaining interstitial waters from consolidated and unconsolidated sediments. U. S. Geological Survey Professional Paper, 550-C:256-261.

Miyazaki, S., and Heki, K., 2001. Crustal velocity field of southwest Japan: subduction and arc-arc collision. Journal of Geophysical Research: Solid Earth, 106(B3):43054326. http://dx.doi.org/10.1029/2000JB900312

Moore, G., Kanagawa, K., Strasser, M., Dugan, B., Maeda, L., and Toczko, S., 2014. IODP Expedition 338: NanTroSEIZE Stage 3: NanTroSEIZE plate boundary deep riser 2. Scientific Drilling, 17:1-12. http://dx.doi.org/10.5194/ sd-17-1-2014

Murray, R.W., Miller, D.J., and Kryc, K.A., 2000. Analysis of major and trace elements in rocks, sediments, and interstitial waters by inductively coupled plasma-atomic emission spectrometry (ICP-AES). Ocean Drilling Program Technical Note, 29. http://dx.doi.org/10.2973/ odp.tn.29.2000

Oi, T., Kato, J., Ossaka, T., and Kakihana, H., 1991. Boron isotope fractionation accompanying boron mineral formation from aqueous boric acid-sodium hydroxide solutions at $25^{\circ} \mathrm{C}$. Geochemical Journal, 25(5):377-385. http://dx.doi.org/10.2343/geochemj.25.377

Palmer, M.R., Spivack, A.J., and Edmond, J.M., 1987. Temperature and $\mathrm{pH}$ controls over isotopic fractionation during adsorption of boron on marine clay. Geochimica et Cosmochimica Acta, 51(9):2319-2323. http:// dx.doi.org/10.1016/0016-7037(87)90285-7

Saffer, D., McNeill, L., Araki, E., Byrne, T., Eguchi, N., Toczko, S., Takahashi, K., and the Expedition 319 Scientists, 2009. NanTroSEIZE Stage 2: NanTroSEIZE riser/riserless observatory. Integrated Ocean Drilling Program Preliminary Report, 319. http://dx.doi.org/10.2204/ iodp.pr.319.2009

Seno, T., Stein, S., and Gripp, A.E., 1993. A model for the motion of the Philippine Sea plate consistent with NUVEL-1 and geological data. Journal of Geophysical Research: Solid Earth, 98(B10):17941-17948. http:// dx.doi.org/10.1029/93JB00782

Spivack, A.J., and Edmond, J.M., 1987. Boron isotope exchange between seawater and the oceanic crust. Geochimica et Cosmochimica Acta, 51(5):1033-1043. http:// dx.doi.org/10.1016/0016-7037(87)90198-0

Strasser, M., Dugan, B., Kanagawa, K., Moore, G.F., Toczko, S., Maeda, L., Kido, Y., Moe, K.T., Sanada, Y., Esteban, L., Fabbri, O., Geersen, J., Hammerschmidt, S., Hayashi, H., Heirman, K., Hüpers, A., Jurado Rodriguez, M.J., Kameo, K., Kanamatsu, T., Kitajima, H., Masuda, H., Milliken, K., Mishra, R., Motoyama, I., Olcott, K., Oohashi, K., Pickering, K.T., Ramirez, S.G., Rashid, H., Sawyer, D., Schleicher, A., Shan, Y., Skarbek, R., Song, I., Takeshita, T., Toki, T., Tudge, J., Webb, S., Wilson, D.J., Wu, H.-Y., and Yamaguchi, A., 2014. Methods. In Strasser, M., Dugan, B., Kanagawa, K., Moore, G.F., Toczko, S., Maeda, L., and the Expedition 338 Scientists, Proceedings 
of the Integrated Ocean Drilling Program, 338: Yokohama (Integrated Ocean Drilling Program). http://

dx.doi.org/10.2204/iodp.proc.338.102.2014

Teichert, B.M.A., Torres, M.E., Bohrmann, G., and Eisenhauer, A., 2005. Fluid sources, fluid pathways and diagenetic reactions across an accretionary prism revealed by $\mathrm{Sr}$ and B geochemistry. Earth and Planetary Science Letters, 239(1-2):106-121. http://dx.doi.org/10.1016/ j.eps1.2005.08.002

Underwood, M.B., Saito, S., Kubo, Y., and the Expedition 322 Scientists, 2010. Expedition 322 summary. In Saito, S., Underwood, M.B., Kubo, Y., and the Expedition 322 Scientists, Proceedings of the Integrated Ocean Drilling Program, 322: Tokyo (Integrated Ocean Drilling Program Management International, Inc.). http://dx.doi.org/ 10.2204/iodp.proc.322.101.2010

Wang, B.-S., You, C.-F., Huang, K.-F., Wu, S.-F., Aggarwal, S.K., Chung, C.-H., and Lin, P.-Y., 2010. Direct separation of boron from Na- and Ca-rich matrices by sublimation for stable isotope measurement by MC-ICP-MS. Talanta, 82(4):1378-1384. http://dx.doi.org/10.1016/ j.talanta.2010.07.010

Williams, L.B., Hervig, R.L., Holloway, J.R, and Hutcheon, I., 2001. Boron isotope geochemistry during diagenesis. Part I. Experimental determination of fractionation during illitization of smectite. Geochimica et Cosmochimica Acta, 65(11):1769-1782. http://dx.doi.org/ 10.1016/S0016-7037(01)00557-9
You, C.-F., Chan, L.H., Spivack, A.J., and Gieskes, J.M., 1995. Lithium, boron, and their isotopes in sediments and pore waters of Ocean Drilling Program Site 808, Nankai Trough: implications for fluid expulsion in accretionary prisms. Geology, 23(1):37-40. http:// dx.doi.org/10.1130/ 0091-7613(1995)023<0037:LBATII>2.3.CO;2

You, C.-F., and Gieskes, J.M., 2001. Hydrothermal alteration of hemi-pelagic sediments: experimental evaluation of geochemical processes in shallow subduction zones. Applied Geochemistry, 16(9-10):1055-1066. http:/ /dx.doi.org/10.1016/S0883-2927(01)00024-5

You, C.-F., Spivack, A.J., Gieskes, J.M., Martin, J.B., and Davisson, M.L., 1996. Boron contents and isotopic compositions in pore waters: a new approach to determine temperature induced artifacts-geochemical implications. Marine Geology, 129(3-4):351-361. http:// dx.doi.org/10.1016/0025-3227(96)83353-6

You, C.-F., Spivack, A.J., Smith, J.H., and Gieskes, J.M., 1993. Mobilization of boron in convergent margins: implications for the boron geochemical cycle. Geology, 21(3):207-210. http://dx.doi.org/10.1130/ 0091-7613(1993)021<0207:MOBICM>2.3.CO;2

Initial receipt: 6 May 2015

Acceptance: 14 October 2015

Publication: 8 December 2015

MS 338-203 
Figure F1. A. Location map of the Nankai Trough showing NanTroSEIZE Stage 1, 2, and 3 drill sites and Ocean Drilling Program Site 808 off Muroto. (Continued on next page.)

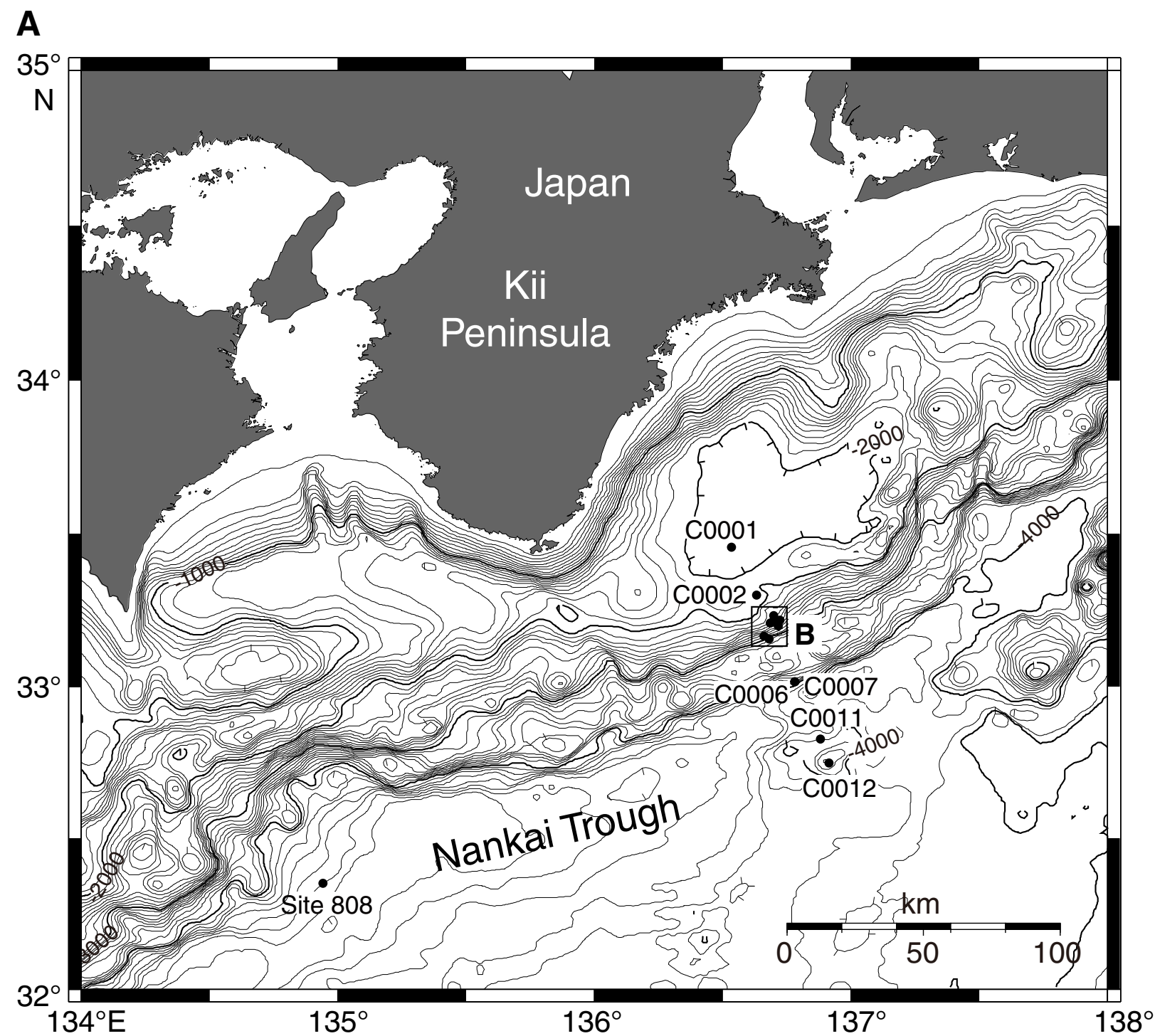


Figure F1 (continued). B. Detailed bathymetry showing Expedition 338 sites in relation to NanTroSEIZE Stage 1 and 2 sites.

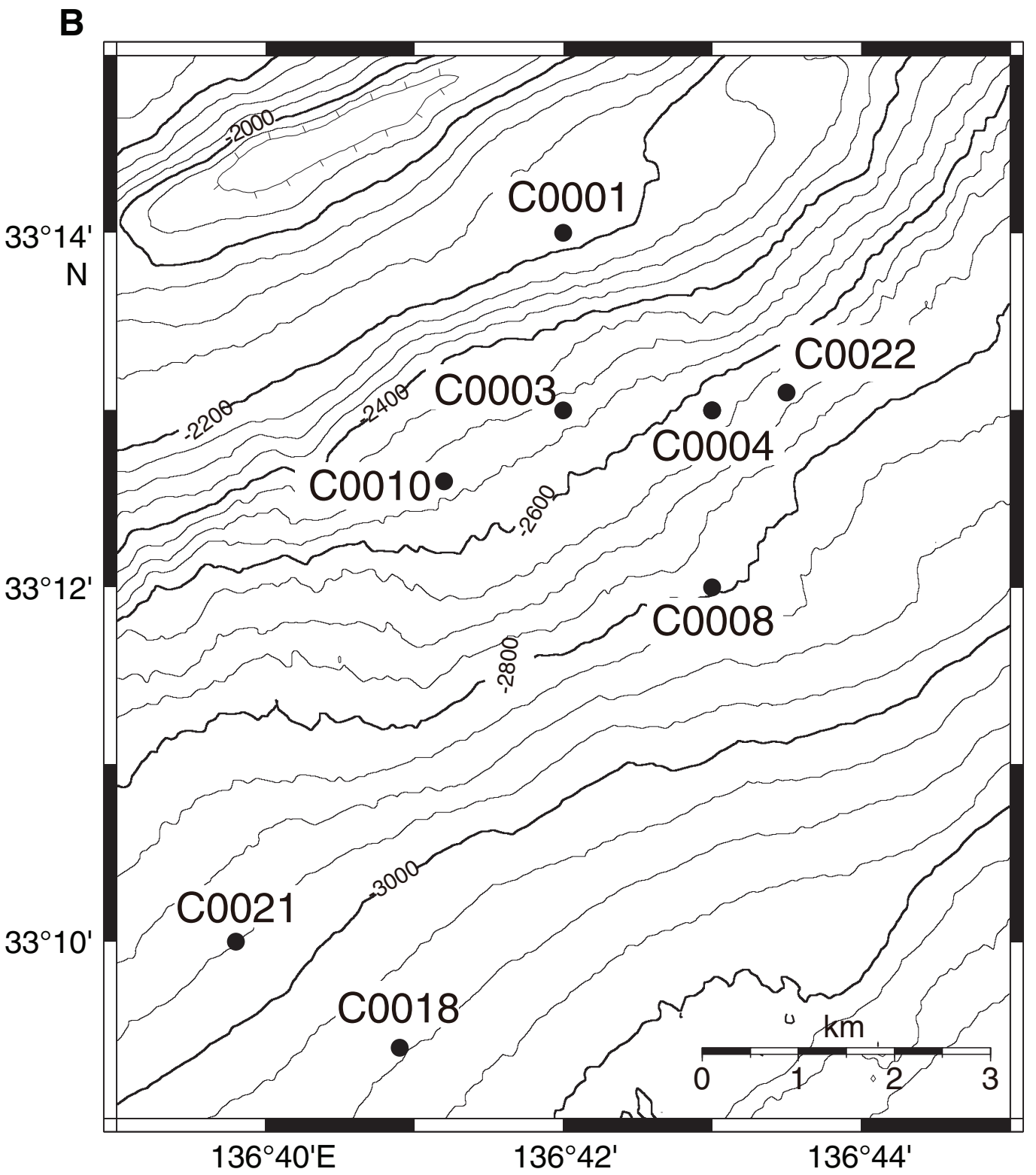


Figure F2. Depth profiles of total dissolved B concentration and $\delta^{11} \mathrm{~B}$, Site C0021. Shaded areas = mass transport deposits.
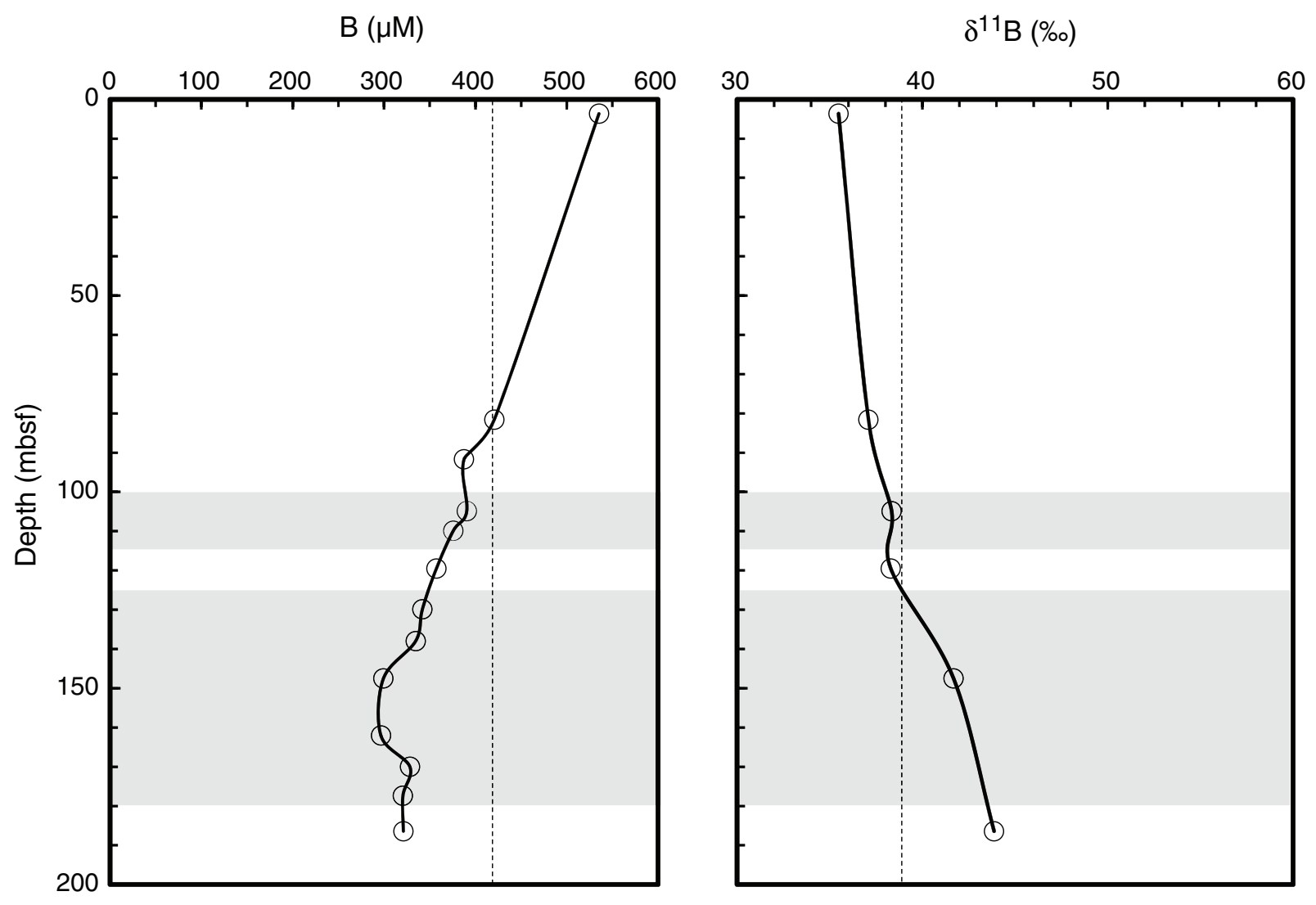
Figure F3. Depth profiles of total dissolved B concentration and $\delta^{11} \mathrm{~B}$, Site C0022. Dark gray area = megasplay fault, light gray area $=$ deformation related to the fault.

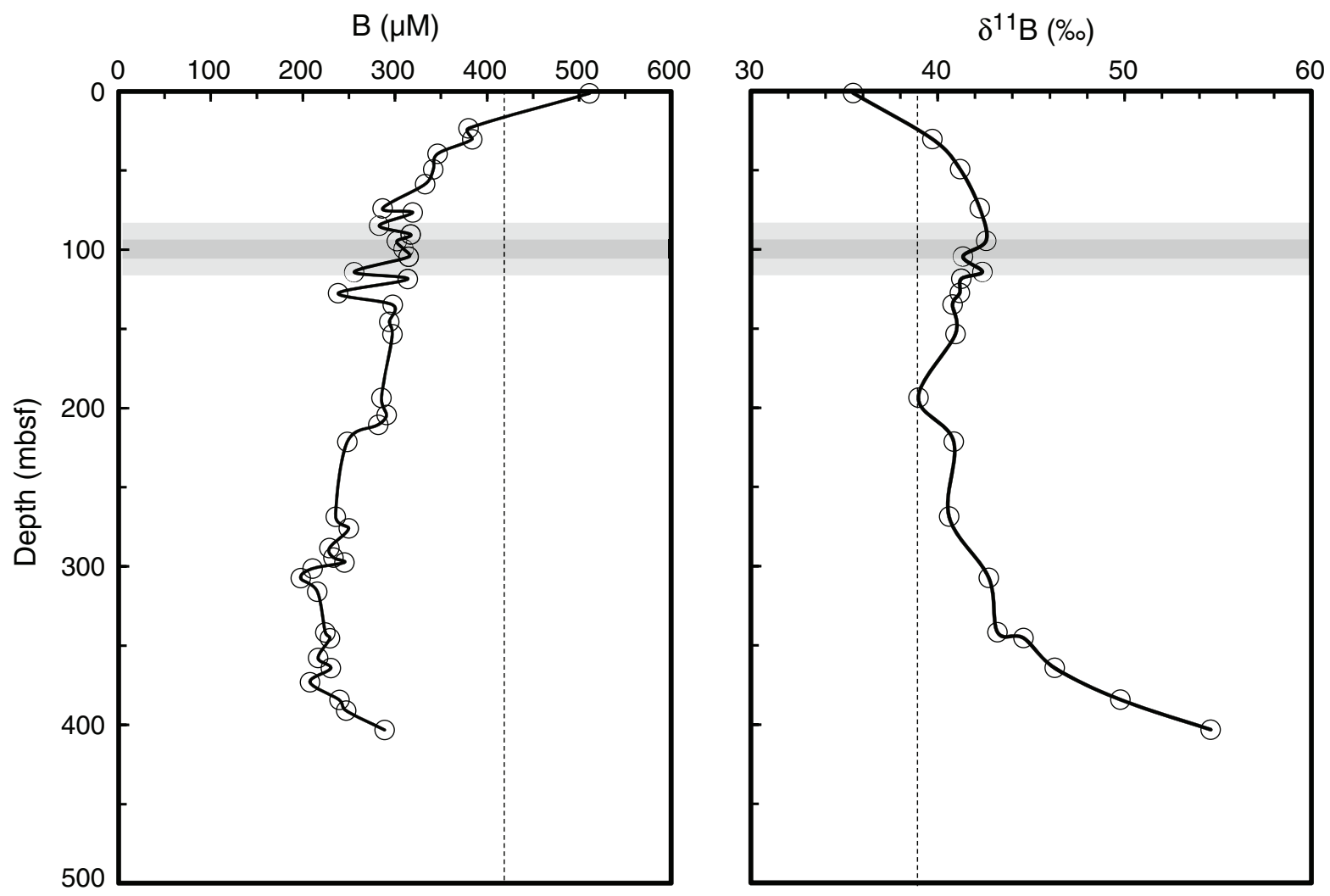


Table T1. Boron concentrations and $\delta^{11} \mathrm{~B}$ in interstitial waters, Expedition 338 Sites C0021 and C0022.

\begin{tabular}{|c|c|c|c|c|c|}
\hline Location & $\begin{array}{l}\text { Core, section, } \\
\text { interval }(\mathrm{cm})\end{array}$ & $\begin{array}{l}\text { Depth } \\
\text { (mbsf) }\end{array}$ & $\begin{array}{c}B \\
(\mu M)\end{array}$ & $\begin{array}{l}\delta^{11} \mathrm{~B} \\
(\% \mathrm{o})\end{array}$ & $\begin{array}{l}2 \sigma \\
(\% o)\end{array}$ \\
\hline \multirow[t]{14}{*}{$33^{\circ} 10.0555^{\prime} \mathrm{N}, 136^{\circ} 39.8610^{\prime} \mathrm{E}$} & 338-C0021B- & & & & \\
\hline & $1 \mathrm{H}-4$ & 3.7 & 535 & 35.5 & 0.06 \\
\hline & $2 \mathrm{H}-3$ & 81.6 & 421 & 37.1 & 0.05 \\
\hline & $3 \mathrm{H}-4$ & 91.7 & 388 & - & - \\
\hline & $4 \mathrm{H}-6$ & 104.9 & 391 & 38.3 & 0.05 \\
\hline & $5 \mathrm{H}-2$ & 109.9 & 376 & - & - \\
\hline & $6 \mathrm{H}-3$ & 119.5 & 357 & 38.3 & 0.05 \\
\hline & $7 \mathrm{H}-4$ & 129.9 & 342 & - & - \\
\hline & $8 \mathrm{H}-2$ & 138.0 & 335 & - & - \\
\hline & $9 \mathrm{H}-2$ & 147.5 & 299 & 41.7 & 0.05 \\
\hline & $10 \mathrm{H}-8$ & 162.1 & 297 & - & - \\
\hline & $12 \mathrm{H}-2$ & 170.0 & 328 & - & - \\
\hline & $13 \mathrm{~T}-3$ & 177.4 & 321 & - & - \\
\hline & $14 \mathrm{~T}-2$ & 186.4 & 321 & 43.9 & 0.06 \\
\hline \multirow[t]{40}{*}{$33^{\circ} 13.0833^{\prime} \mathrm{N}, 136^{\circ} 43.4667^{\prime} \mathrm{E}$} & 338-C0022B- & & & & \\
\hline & $1 \mathrm{H}-2,0-20$ & 1.2 & 511 & 35.5 & 0.06 \\
\hline & $2 \mathrm{H}-5,0-8.5$ & 23.4 & 380 & - & - \\
\hline & $3 \mathrm{H}-2,0-10.5$ & 30.3 & 384 & 39.7 & 0.05 \\
\hline & $4 \mathrm{H}-2,0-20$ & 39.5 & 346 & - & - \\
\hline & $5 \mathrm{H}-2,0-20$ & 49.3 & 342 & 41.2 & 0.05 \\
\hline & $6 \mathrm{H}-2,0-20.5$ & 58.6 & 333 & - & - \\
\hline & $7 \mathrm{H}-7,12-31.5$ & 74.0 & 286 & 42.2 & 0.06 \\
\hline & $8 \mathrm{H}-1,0-20$ & 76.5 & 319 & - & - \\
\hline & $9 \mathrm{~T}-2,0-21$ & 84.8 & 283 & - & - \\
\hline & 10T-2, 0-21 & 90.3 & 317 & - & - \\
\hline & $11 \mathrm{~T}-1,0-4$ & 94.5 & 302 & 42.6 & 0.06 \\
\hline & $12 X-1,120.4-140.5$ & 99.5 & 309 & - & - \\
\hline & $13 X-1,30-50$ & 104.5 & 315 & 41.4 & 0.07 \\
\hline & $14 X-4,60-80$ & 114.1 & 256 & 42.4 & 0.05 \\
\hline & $15 X-3,110-130$ & 118.5 & 314 & 41.3 & 0.06 \\
\hline & $16 X-4,0-27$ & 127.5 & 238 & 41.2 & 0.05 \\
\hline & $17 X-2,11-32$ & 134.8 & 298 & 40.8 & 0.05 \\
\hline & $18 X-4,0-21.5$ & 145.6 & 294 & - & - \\
\hline & $19 X-2,10-31.5$ & 153.4 & 297 & 40.9 & 0.05 \\
\hline & $20 X-4,0-21.5$ & 193.6 & 285 & 39.0 & 0.05 \\
\hline & $21 X-6,0-22$ & 204.3 & 291 & - & - \\
\hline & $22 X-1,98-118$ & 210.5 & 282 & - & - \\
\hline & $23 X-4,0-25$ & 221.2 & 248 & 40.9 & 0.05 \\
\hline & $24 X-3,0-30.5$ & 268.7 & 236 & 40.6 & 0.05 \\
\hline & $25 X-1,0-7.5$ & 276.0 & 250 & - & - \\
\hline & $26 \mathrm{X}-3,0-30$ & 288.3 & 229 & - & - \\
\hline & $27 X-4,0-31$ & 294.3 & 233 & - & - \\
\hline & $28 X-3,0-35$ & 297.4 & 245 & - & - \\
\hline & $29 X-2,0-40.5$ & 301.3 & 210 & - & - \\
\hline & $30 X-3,0-41$ & 307.3 & 198 & 42.7 & 0.05 \\
\hline & $31 X-2,0-39.5$ & 315.9 & 216 & - & - \\
\hline & $33 X-7,0-40.5$ & 341.7 & 224 & 43.2 & 0.05 \\
\hline & $34 X-3,0-41$ & 345.4 & 229 & 44.6 & 0.06 \\
\hline & $35 X-5,0-40$ & 357.8 & 216 & - & - \\
\hline & $36 X-3,0-41$ & 364.2 & 230 & 46.3 & 0.05 \\
\hline & $37 X-2,17-39.5$ & 373.1 & 208 & - & - \\
\hline & $38 X-3,0-40$ & 384.3 & 240 & 49.8 & 0.06 \\
\hline & $39 \times-2,0-41$ & 391.0 & 247 & - & - \\
\hline & $40 X-3,0-41$ & 403.2 & 289 & 54.6 & 0.05 \\
\hline
\end{tabular}

$-=$ data not analyzed. 